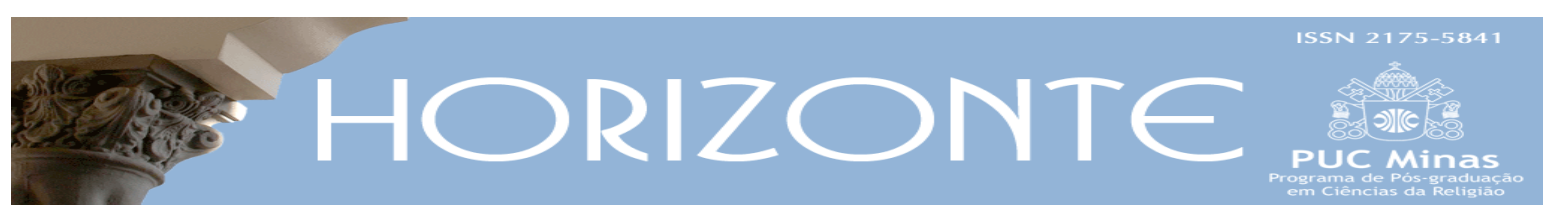

Dossiê: Religião e Educação - Artigo original (c)

DOI - 10.5752/P.2175-5841.2020v18n55p77

\title{
Ensino Religioso: \\ um campo de aplicação da Ciência da Religião
}

\author{
Religious Education: \\ a field of Applied Science of Religion
}

Elisa Rodrigues*

\begin{abstract}
Resumo
O artigo a seguir representa um esforço de síntese sobre a narrativa da formação do Ensino Religioso nos documentos oficiais brasileiros relacionados à Educação. Assim, pretende ser um instrumento teóricopedagógico para a compreensão desse componente curricular como um campo da Ciência Aplicada da Religião. Para alcançar esse objetivo dividimos o texto em três partes. Na primeira parte são abordadas as possíveis classificações do Ensino Religioso, que seriam: subárea de conhecimento das Ciências da Religião - CRE ou, Ciências da Religião Aplicada e componente curricular, que compõem o conjunto das disciplinas oferecidas no nível do Ensino Fundamental brasileiro. Na segunda parte do artigo são discutidos alguns elementos dos documentos oficiais, a Base Nacional Comum Curricular (2017) e as Diretrizes Curriculares Nacionais para Licenciaturas em Ciência da Religião (2018), que asseguram a oferta do Ensino Religioso, segundo um modelo reflexivo e laico. Por fim, na terceira parte são apresentados e discutidos alguns pressupostos epistemológicos e metodológicos das CRE, que servem à fundamentação teórica e prática do Ensino Religioso.
\end{abstract}

Palavras-chave: Ensino Religioso. Ciência da Religião Aplicada. Subárea de Conhecimento. Componente Curricular. Religião e Educação.

\begin{abstract}
The following article represents a synthesis effort on the narrative of Religious Education formation in the Brazilian official documents on Education. Thus, it intends to be a theoretical and pedagogical instrument for understanding this curricular component as a field of Applied Science of Religion. In order to achieve this goal, we divide the text into three parts. In the first part, the possible classifications of Religious Education, which would be the subarea of knowledge of the Science of Religion or the Applied Science of Religion and the curricular component that composes the subjects defined at the Brazilian Elementary School level. In the second part of this article some elements of the official documents are discussed, the Common National Curriculum Base (2017) and the National Curriculum Guidelines for Licenciature of Science in Religion (2018), which guarantee the provision of Religious Education in accordance with the Law and a reflective and secular model of education. At the end, we will present and discuss in the third part some epistemological and methodological assumptions of the Science of Religion that allow the theoretical and practical basis of Religious Education.

Keywords: Religious Education. Applied Science of Religion. Subarea of the Knowledge. Curricular component. Religion and Education.
\end{abstract}

Artigo submetido em 13 de janeiro de 2020 e aprovado em 20 de abril de 2020.

* Doutora em Ciências da Religião pela UMESP. Professora da UFJF. País de origem: Brasil. E-mail: elisa.erodrigues@gmail.com 


\section{Introdução}

No Brasil, a área de conhecimento Ciências da Religião (CRE) ultrapassou o estágio da construção, avançou a fase da legitimação no Campo das Humanidades e, atualmente, caminha pela senda da consolidação. Este artigo objetiva discutir a relação dos estudos de religião com um importante nicho que tem contribuído para o processo de consolidação das CRE brasileira: a Educação.

Para tanto, dividimos o artigo em três partes. A primeira aborda a classificação Ensino Religioso como subárea de conhecimento, destacando que elementos a caracterizam como componente curricular (ou, como se dizia anteriormente, disciplina). A segunda parte deste artigo versa sobre o Ensino Religioso nos documentos Base Nacional Comum Curricular (2017) ${ }^{1}$ e Diretrizes Curriculares Nacionais para Licenciaturas em Ciência da Religião (2018)², indicando em que medida esses documentos atendem às orientações da Lei de Diretrizes de Bases da Educação (1996)3, apresentando textos complementares. Por fim, na terceira parte pretende-se discutir alguns pressupostos epistemológicos e metodológicos das CRE, que servem à fundamentação teórica e prática do Ensino Religioso. Noutras palavras, "como" a teoria dos estudos de religião desenvolvidos pelas CRE brasileira podem ser aplicados no âmbito do Ensino Religioso.

Este artigo não pretende ser uma apresentação histórica da trajetória das CRE no Brasil, tampouco do ER. Mas, ao mapear e definir concepções tais como área, campo, componente e aplicação, possivelmente, poderá ser tomado como um instrumento para o entendimento de uma narrativa de longa trajetória, a qual chamamos aqui Ensino Religioso: Um campo de aplicação da Ciência da Religião.

\footnotetext{
${ }^{1}$ Homologada pela Portaria MEC no 1.570/2017.

${ }^{2}$ Portaria $n^{\circ} 1.403$, PARECER CNE/CP N ${ }^{\circ} 12 / 2018$.

${ }^{3}$ LDB n. 9.394/1996 (artigo 33, alterado pela Lei n. 9.475/1997).
} 


\section{O Ensino Religioso: (Sub)Área de Conhecimento das Ciências da Religião? Aplicada e Componente Curricular}

Três dimensões constituem uma Área de conhecimento sobre um objeto específico. Essas dimensões dialogam entre si e podem ser assim classificadas: (a) a dimensão do saber específico, (b) a dimensão do referencial teórico e (c) a dimensão da metodologia. Ao consentirmos com a noção de que o Ensino Religioso é um campo de aplicação do conhecimento produzido pela área das CRE e um componente curricular, conforme consta na BNCC (2017, p. 434)4, estamos concordando que o ER tem um saber específico que é o conhecimento religioso que nos termos das Ciência(s) da Religião é entendido como fenômeno religioso. A fim de conhecer esse fenômeno existem enquadramentos teóricos que discutem e analisam esse fenômeno (de abordagens teóricas idealizadas por diferentes estudiosos) e que, a fim de abordá-lo, há um ou mais percursos metodológicos disponíveis. Cada qual, responsável por uma forma de se interpretar o fenômeno religioso. 5

Com o objetivo de orientar as Instituições de Ensino, pesquisa e inovação, o Conselho Nacional de Desenvolvimento Científico e Tecnológico (CNPq) formulou um sistema de classificação, dividido em quatro níveis: 1) as Grande Áreas que totalizam nove e apresentam afinidade quanto ao objeto, métodos e instrumentos teóricos; 2) as Áreas básicas que totalizam quarenta e oito e são chamadas áreas de avaliação da Coordenação de Aperfeiçoamento de Pessoal de Nível Superior (CAPES); 3) as Sub-áreas que são segmentos das áreas de conhecimento e 4) as Especialidades, caracterizadas por serem temáticas interessadas em atividades voltadas para a pesquisa e ensino.

De acordo com esse esquema classificatório do CNPq/CAPES, a Grande Área em que estão alocados os estudos de religião é o Campo das Humanidades ou as

\footnotetext{
${ }^{4}$ A respeito desse documento falaremos adiante.

${ }^{5}$ Como dito, essas dimensões dialogam entre si de modo a abordar o fenômeno religioso a partir de uma perspectiva. Por exemplo, do ponto de vista de um enquadramento teórico-metodológico funcionalista destaca-se a função que o objeto exerce no âmbito de uma cultura, um sistema de leis, um grupo social etc. De um ponto de vista teórico-metodológico antropológico evidencia-se pela descrição etnográfica como o objeto se insere em redes de sentido estabelecidas pelas pessoas.
} 
Ciências Humanas. Integram essa Grande Área, outras Áreas do conhecimento básicas como: Teologia, Filosofia, História, Sociologia, Antropologia, Arqueologia, Geografia, Psicologia, Educação e Ciência Política.

Inicialmente, a Teologia (Teo) e as Ciências da Religião (CRE) no Brasil foram classificadas como Subáreas da Filosofia. Mas, em 2017, foram emancipadas da Filosofia e ganharam lugar próprio na árvore dos saberes do CNPq/CAPES, sob a classificação de Área 44 - Ciências da Religião e Teologia. ${ }^{6}$ Isto significa que, segundo a classificação do CNPq/CAPES, a "Ciências da Religião" é uma Área de conhecimento caracterizada por ter um objeto específico (o fenômeno religioso), um quadro teórico e um conjunto de aportes metodológicos multi/transdisciplinar.

Considerada essa realidade, bem como o respeito àqueles/as que não se orientam por tais práticas ou quaisquer crenças religiosas, faz-se necessário um saber qualificado e crítico de corte teológico e/ou da ciência(s) da(s) religião(ões). O fenômeno religioso percebido em sua totalidade, considerados os seus elementos constitutivos, assim como a análise crítica da fé e de seus desdobramentos na dinâmica da comunidade dos crentes de uma dada confissão são passíveis de uma abordagem de corte acadêmicocientífico. (SENRA, 2019, p. 12, grifo nosso).

Dentro dessa lógica, o Ensino Religioso foi entendido como uma das oito Subáreas das CRE por constituírem uma forma de aplicação das Ciências da Religião; por isso, Ciências da Religião Aplicada (MINISTÉRIO DA EDUCAÇÃO E CULTURA, 2019b, p. 3-4).

Assim, embora inicialmente na BNCC o ER tenha sido considerado uma área de conhecimento, em decorrência da resolução do CNE/CEB n.07/2010 na qual o ER foi enquadrado como uma quinta área de conhecimento, cabe compreender que sua ciência de referência são as CRE e que seria mais adequado compreendê-lo como importante segmento da área de CRE. Portanto, na qualidade de uma subárea

\footnotetext{
6 “A Área Ciências da Religião e Teologia, código 44, surgiu com a Portaria CAPES no 174/2016, publicada no DOU de 13 de outubro de 2016, redesignada pela Resolução no 01, de 04 de abril de 2017, publicada no Boletim de Serviço/CAPES - Edição Especial no 1 - abril 2017. Com 47 anos de existência, os Programas de Pós-graduação (PPG) da atual área Ciências da Religião e Teologia compunham, até outubro de 2016, a extinta área Filosofia/Teologia: subcomissão Teologia. A portaria acima mencionada criou as áreas de Filosofia e de Teologia, sendo esta renomeada, posteriormente, como Ciências da Religião e Teologia". Cf. Ministério da Educação e cultura (2019b, p. 3).
} 
das CRE que compõe o campo das Humanidades, o ER se insere no currículo do Ensino Fundamental como um componente curricular. Esse foi, aliás, o entendimento da Câmara de Educação Básica que por meio do parecer $\mathrm{CNE} / \mathrm{CEB}$ 8/2019 recomendou a alteração do artigo 15 da Resolução CNE/CEB n ${ }^{0}$ 7, de 14/12/2010 (em conformidade com o CNE/CP $n^{0} 2 / 2017$ ), o qual fixa DCNs para o Ensino Fundamental (Primeiro ao novo ano7). Segundo o parecer de 2019, o Ensino Religioso deve ser considerado componente curricular da área de Ciências Humanas e não mais área de conhecimento ${ }^{8}$.

Por Componente Curricular compreende-se o conjunto de elementos que constituem o currículo dos cursos que serão ofertados aos educandos e educandas, de acordo com os documentos oficiais (DCNs, BNCC, planos de educação ou currículos estaduais e municipais). A dicção do texto constitucional afirma que a educação obrigatória deve ser de qualidade, o que implica garantir que todos(as) discentes participem de aulas de todos os componentes curriculares.

Essa garantia do Estado pressupõe que:

Valores, atitudes, sensibilidade e orientações de conduta são veiculados não só pelos conhecimentos, mas por meio de rotinas, rituais, normas de convívio social, festividades, pela distribuição do tempo e organização do espaço educativo, pelos materiais utilizados na aprendizagem e pelo recreio, enfim, pelas vivências proporcionadas pela escola. ${ }^{9}$

Sobre esse ponto deve-se considerar que esse entendimento tem sido construído gradativamente e não sem discordâncias. Assim como entre docentes de

\footnotetext{
${ }^{7}$ Entende-se o Ensino Fundamental como etapa da educação que assegura aos educandos e educandas o acesso a um conjunto de conhecimentos imprescindíveis ao desenvolvimento dos sujeitos, individualmente e em sociedade. Deve-se atinar para o fato de que os componentes curriculares que compõem um currículo são constituídos de conteúdos explícitos e implícitos igualmente relevantes, que perpassam os diversos componentes curriculares ligados às diferentes áreas de conhecimento.

8 “CÂMARA DE EDUCAÇÃO BÁSICA Processo: 23001.000168/2009-57 Parecer: CNE/CEB 8/2019 Relator: Ivan Cláudio Pereira Siqueira Interessada: Conselho Nacional de Educação/Câmara de Educação Básica - Brasília/DF Assunto: Altera o artigo 15 da Resolução CNE/CEB no 7, de 14 de dezembro de 2010, que "[...] fixa Diretrizes Curriculares Nacionais para o Ensino Fundamental de 9 (nove) anos" Voto do Relator: Face ao exposto, em atendimento ao artigo 23 da Resolução CNE/CP no 2/2017, este Relator sugere que o Ensino Religioso deixe de ser Área de Conhecimento do Ensino Fundamental, conforme estabelecido no artigo 15 da Resolução CNE/CEB no 7/2010, e passe a ser componente curricular da área de Ciências Humanas, no Ensino Fundamental Decisão da Câmara: APROVADO por unanimidade". Cf. Ministério da Educação (2019a, p. 246).

${ }^{9}$ Cf. Artigo 9‥ Parágrafo 2. Cf. Resolução CNE/CEB 7/2010. Diário Oficial da União, Brasília, 15 de dezembro de 2010, Seção 1, p. 34.
} 
ER existem dúvidas quanto ao vínculo entre CRE e ER ${ }^{10}$, também entre gestores e especialistas ligados ao MEC pairam desacertos sobre a autocompreensão da disciplina/componente curricular (da função), sobre a sua natureza sociocultural (das habilidades que produz) e a respeito da sua natureza pedagógica (da elaboração de objetos do conhecimento e da formação dos professores). ${ }^{11}$ Isto, em certa medida, tem a ver com a novidade da área de CRE, tanto entre especialistas quanto entre professores e professoras que lecionam o componente curricular Ensino Religioso. Entrementes, essa dificuldade acena para outro problema que não cabe discutir neste artigo, qual seja: o da formação docente especializada para o Ensino Religioso.

Retomando a questão do ER como subárea das CRE e componente curricular do Ensino Fundamental, até onde se sabe ${ }^{12}$, o primeiro trabalho acadêmico que vislumbrou o casamento entre CRE e ER foi publicado por João Décio Passos (2007). Depois dele Afonso Maria Ligório Soares (2010) publicou um livro tematizando a relação entre religião e educação. Em 2013, novamente, João D. Passos, agora, juntamente com Frank Usarski, organizaram o Compêndio de Ciência da Religião, em que foi dedicada uma sessão para discussão das áreas de Aplicação da Ciência da Religião, dentre as quais, o Ensino Religioso.

\footnotetext{
${ }^{10}$ Por ser as CRE um campo de estudos relativamente novo e desconhecido para grande parte do corpo docente no Ensino Fundamental, a aproximação entre essa área e o ER nem sempre é compreendida. Muitas vezes sequer é considerada necessária, considerando que em sua trajetória tem se servido dos aportes teóricos da Teologia, da História e das Ciências Sociais. Além de quê para muitos professores e professoras de ER espalhados pelo território nacional, a prática do ER desassistida pelo Estado lhes impôs a necessidade de criação de seus próprios currículos e planejamentos de aulas. Para suprir a ausência de parâmetros oficiais muitos professores e professoras utilizaram os Parâmetros Curriculares Nacionais do ER (1997; 2010), produzidos pelo Fórum Nacional Permanente do Ensino Religioso (FONAPER). Um material que foi oficializado na e pela prática docente e, desde então, tornou-se o subsídio pedagógico mais utilizado no território nacional. A discussão sobre uma área de referência para o ER venho à tona nos anos 2000, a partir dos Congressos Nacionais de Ensino Religioso, organizados pelo FONAPER. Neste sentido, a questão que se coloca para muitos desses e dessas docentes que lecionam o ER tem relação com a formação específica, que até o ano 2018 não havia sido ainda regulada.

${ }^{11} \mathrm{Na}$ discussão da BNCC, o ER inicialmente teria sido alocado na área de Ciências Humanas, mas em decorrência dos debates em torno da legitimidade desse componente curricular e da disputa pelo objeto específico (o fenômeno religioso) permaneceu sob o título de área de conhecimento autônoma (Resolução do CNE/CEB 07/2010), enquanto Geografia e História, por exemplo, foram classificadas como componentes curriculares: "Estudar Geografia é uma oportunidade para compreender o mundo em que se vive, na medida em que esse componente curricular aborda as ações humanas construídas nas distintas sociedades existentes nas diversas regiões do planeta" (BNCC, 2017, p. 359, negrito nosso). O parecer CNE/CEB 8/2019, neste sentido, não apenas dá novo nome ao ER e novo lugar no interior da BNCC, mas também the confere o status de um componente que, dentro de um programa de ensino, tem a especificidade de dar tratamento a um tipo de conhecimento relevante para a vida social, que é o fenômeno religioso.

${ }^{12}$ Motivado pela pergunta "qual a concepção de ciência da religião subjacente a cada projeto pedagógico?", Frederico Piper publicou uma pesquisa sobre a trajetória da licenciatura em Ciência da Religião na Universidade Federal de Juiz de Fora. A análise demonstrou como os projetos políticos e pedagógicos propostos em 1971, 1980, 1990 e 2011 revelam distinções quanto à noção de Ciência da Religião em cada um desses períodos históricos. É notável que em todas essas fases, o Ensino Religioso emergiu como preocupação dos envolvidos(as) com o curso que já demonstravam interesse numa aproximação com o ER numa perspectiva reflexiva e compreensiva. (PIEPER, 2018).
} 
Desde então outras pesquisas tem sido realizadas, algumas em debate com a perspectiva de Udo Tworuschka (2013; 2018), que visa uma distinção entre uma Ciência da Religião Pura e uma Ciência Prática da Religião e outras em diálogo com Donald Wiebe (2005), para quem os Estudos de Religião não devem ater-se às questões empíricas ou da vida prática, justamente porque não haveria uma natureza social nesse campo. No contexto brasileiro, vale destacar a publicação de Ciência da Religião Aplicada: Ensaios pela autonomia e aplicação profissional (STERN; COSTA, 2018), um produto do Seminário de Ciência da Religião Aplicada, organizado desde 2017 pela Pontifícia Universidade Católica de São Paulo. ${ }^{13}$

Dentro desse quadro como tem se desenhado o ER? Quais paradigmas podem ser empregados na abordagem do fenômeno religioso na escola pública?

De início faz-se necessário indicarmos o que constitui o objeto do ER por excelência, bem como um conceito do que seja esse objeto, mesmo que reconhecendo a insuficiência e os limites das conceituações teóricas. ${ }^{14}$

Dito isso, propomos que o objeto do ER é a religião ou o religioso, termos aqui empregados de modo semelhante às expressões fenômeno religioso, fato religioso e ou tradições religiosas. Mesmo que as acepções de tais termos sejam diferentes entre si, porque remontam à, respectivamente, 1) questões filosóficas do fenômeno como aparece - , 2) questões sociológicas - daquilo que social e historicamente se impõe como realidade externa, generalizante e coercitiva ${ }^{15}$ - e, por fim, 3) questões hermenêuticas, da tradição enquanto horizonte de sentido. Assim, ao se utilizar religião e religioso subentende-se que tais termos constituem referências para algo que no campo empírico não se encontra materializado numa expressão singular.

\footnotetext{
${ }^{13}$ Disponível em: http://congressos.pucsp.br/index.php/SEMCREA/2020/schedConf/overview. Acesso em: 18 dez. 2019.

${ }^{14}$ Para uma discussão sobre o conceito de religião, seus limites e possibilidades de compreensão, veja-se o artigo Religião: limites $e$ horizontes de um conceito (PIEPER, 2019).

${ }^{15}$ Régis Debray (2002) usa o termo fato religioso para referir-se aos fatos da vida social, lugares (praças, ruas, monumentos etc.), formas de arte material e imaterial (coleções em museus, música, literatura, cinema), conjuntos arquitetônicos (catedrais), festas, datas e outros, que possuem relação com referências religiosas e que se impõem de maneira englobante e coercitiva aos indivíduos, porque integrados à história social e cultural de algumas sociedades (como no caso da francesa).
} 
Logo, a religião ou o religioso são termos referenciais para expressar fenômenos, fatos e tradições ligadas ao religioso, que não se podem conter num único termo ou categoria. Parte-se do entendimento de que a religião é algo que expressa mais do que uma crença ou prática. Ela é também linguagem, discurso, ideologia, poder, instituição social, sistema de classificação, conjunto de práticas, de hábitos, de costumes ${ }^{16}$. Ela é também um tema a ser estudado, analisado e compreendido à luz da razão, com o auxílio de paradigmas teóricos ${ }^{17}$. Paradigmas que vislumbrem a religião a partir de um conceito mais flexível e atento às relações da religião com a sociedade, com as instituições e, de modo geral, com as esferas sociais que fazem parte do cotidiano das pessoas crentes e não-crentes.

O que se observa da religião, por conseguinte, é como se manifesta, quais são e como são construídos os seus discursos (mitos e teologias), quem são suas personagens e atores sociais (tipos de lideranças, adeptos e processos de adesão), que tipo de orientação concedem (doutrinas e códigos de usos e costumes), em que espaços se concretiza (espacialidade) e, que práticas e calendários propõem (rituais). Compreender esse fato ou fenômeno religioso observável e plural pode significar um privilégio único da escola pública, num país republicano e laico (DEBRAY, 2002). Na sociedade contemporânea, tal entendimento compõe o conjunto de habilidades necessárias à formação dos cidadãos e cidadãs. Neste sentido, "Uma escola laica, autêntica e pacificamente, deve conceder a cada estudante acesso à compreensão do mundo" (LANG, 2002, p.12 [Prefácio]. Tradução nossa). ${ }^{18}$

Não se despreza com isso a dimensão da fé, constitutiva do fenômeno religioso. Mas entende-se que aquilo da religião que toca subjetivamente as pessoas religiosas, isto é, a experiência religiosa, somente se pode conhecer por meio das narrativas que as pessoas oferecem. Neste sentido, o que se narra da experiência

\footnotetext{
${ }^{16}$ Além de também ser também concebida por Sigmund Freud (1856-1939), como delírio coletivo.

${ }^{17}$ Para GEARON (2014) existem diferentes paradigmas teóricos a partir dos quais se pode abordar religião na escola. Ele destaca (1) o bíblico-teológico; (2) o fenomenológico; (3) o espiritual-experiencial; (4) o filosófico-conceitual; (5) o sociocultural e o (6) históricopolítico. $\mathrm{O}$ artigo discute o tema tendo em vista que para além do quadro da fé, em que pode-se entender a religião a partir de um olhar interno, o ER contemporâneo deve definir-se pela separação da vida religiosa (sem ignorar que tal tema tangencia a abordagem da religião) e abrir-se para a inclusão nos currículos escolares do pluralismo religioso e das posições não-religiosas.

18 "Une école authentiquement et sereinement laique doit donner à chaque élève accès à la compréhension du monde" (texto original).
} 
religiosa, por exemplo, os testemunhos, também são relevantes para se conhecer o fenômeno religioso. Não cabe nem ao cientista da religião, tampouco ao professor de ER julgar se esse ou aquele relato de experiência corresponderia a uma verdade. Relatos da experiência religiosa são evidências da existência das divindades e ou de entidades espirituais para quem as vivencia.

Para quem estuda, os relatos das experiências religiosas são instrumentos para se conhecer mais daquilo que constitui a fé das pessoas religiosas, assim como relatos de outros tipos de sistemas de crenças ou filosofias de vida: "O Ensino Religioso busca construir, por meio do estudo dos conhecimentos religiosos e das filosofias de vida, atitudes de reconhecimento e respeito às alteridades" (BNCC, 2017, p.435). Atenta a isso, as CRE ao desenvolver o estudo moderno da religião tem se dedicado à compreensão de outros sistemas de crenças que mobilizam narrativas, símbolos, rituais e práticas que atendem a determinadas vontades das pessoas sem, contudo, serem religiosas no sentido mistérico ${ }^{19}$.

Por isso, as CRE se interessam também pelo conteúdo teológico das diferentes tradições religiosas. Conhecer a teologia das religiões proporciona a quem lhes estuda: “(...) a referência ao absoluto (transcendente, último ou Sagrado); a referência ao simbólico e ao ritual; a referência aos lugares de pertença, de tradição e de experiência” (HIGUET, 2006, p. 38). Importa entender que cabe às CRE o interesse pelo desvelamento dos "sentidos" que o fenômeno religioso permite aos religiosos, sem perder de vista os impactos, desdobramentos e influências que esses sentidos terão nas dimensões histórico-políticas, econômicas, culturais e sociais dos religiosos.

Nesse sentido, as CRE como área de conhecimento se qualificam como campo de estudos da religião que fornece instrumentos teóricos, epistemológicos e metodológicos para a abordagem do fenômeno religioso nos currículos escolares, a partir de suas dimensões constitutivas: a simbólica (da interpretação do significado,

\footnotetext{
${ }^{19}$ N. Smart (1983) propôs que além de examinar as religiões e crenças tradicionais, o estudo moderno da religião poderia abordar ideologias seculares (tais como o nacionalismo, o marxismo, o liberalismo, o feminismo e outras) que tentam responder às questões para as quais também a religião elabora respostas (SMART, 1983, p. 42).
} 
sentido) e a histórico-sistemática (da compreensão das origens, da estruturação e da normatividade). Assim, as CRE Aplicadas à Educação se voltam para o ER, a fim de autenticar o saber sobre as religiões como tipo de conhecimento fundamental para uma formação cidadã. Interessa ao ER o conhecimento da religião como uma das dimensões constitutivas da vida humana, na qualidade de conteúdo que perpassa as esferas da vida privada e pública, materializando-se em orientações (ortodoxias e ortopraxias) que dispõem sobre a vida de cidadãos(ãs), individual e coletivamente.

Logo, estudar e compreender a religião ou o religioso, assim como outros sistemas de ideias e crenças chamadas da BNCC de filosofias de vida, significa conhecer um dos elementos presentes no cotidiano das relações sociais, que configura certo conjunto de crenças, ideias e práticas (discursos e ações) que influencia tanto as relações sociais quanto as ações sociais dos indivíduos em sociedade.

\section{Para Soares,}

a compreensão da religião deva ser o verdadeiro objeto do Ensino Religioso, aí se compreendendo o estudo das diferentes manifestações que interferem na formação da sociedade, o qual só pode ser propriamente estudado pela Ciência da Religião. Nesse sentido, o que geralmente é denominado de Ensino Religioso é, na verdade, a transposição didática, ou melhor, a aplicação para o cotidiano da sala de aula dos resultados dessa Ciência, possibilitando aos estudantes da educação básica a compreensão $\mathrm{da}(\mathrm{s})$ cultura(s) das diferentes comunidades que formam determinado país/nação. (SOARES, 2015, p. 46).

Dessa maneira, entende-se o Ensino Religioso como um componente curricular que se destina à produção de saberes sobre as tradições religiosas de determinados grupos, com a finalidade de abordar o conhecimento religioso e fomentar nos/nas estudantes a compreensão sobre uma das dimensões fundamentais que constituem a vida dos indivíduos em sociedade.

Nessa direção, tendemos à concepção de área como algo mais amplo e menos disciplinar (sistemático), com especial atenção a um processo de ensinoaprendizagem atento à dimensão social e ao percurso formativo da cidadania. Uma 
inspiração que visa o incentivo à construção de currículos a partir de conteúdos relevantes e significativos para estudantes, de acordo com suas especificidades regionais, culturais e psicocognitivas.

\section{Ensino Religioso na Base Nacional Comum Curricular (2017) e nas Diretrizes Curriculares Nacionais para as Licenciaturas em Ciências da Religião (2018)}

\subsection{BNCC: propostas e direcionamentos}

Segundo Higuet (2006, p. 45), os estudos de religião se debruçam sobre dois momentos. Um primeiro tem relação com a vivência ou experiência religiosa, os mitos, os símbolos e os ritos, no sentido de que são manifestações da relação entre humanos com um sagrado, uma transcendência, uma completa alteridade ou exterioridade, também conhecida como absoluto ou último. Num segundo momento, os estudos de religião dariam lugar à questão do poder ou da autoridade, dos modos de organização, das relações com o político, das normas morais, das regras de interpretação da literatura de referência, dos sistemas teológicos etc.

Assim como Higuet propõe essa divisão como esquema de estudo e de compreensão do fenômeno religioso, na mesma linha, outros têm proposto fórmulas para se observar, analisar e compreender a relação que se estabelece entre crentes e suas divindades. Não cabe aqui inventariar todas as referências, mas pode-se indicar, entre as tantas, Paul Tillich (1886-1965) e Joachim Wach (1898-1955).

Ambos, em alguma medida falam a respeito de algo do religioso ou da experiência religiosa que é simultaneamente subjetivo e empírico. De Tillich depreende-se que a fé, de dimensão subjetiva, manifesta-se por meio da linguagem: "Sem linguagem não existe fé nem experiência religiosa" (TILLICH, 1985, p.20) e que por meio dessa linguagem eminentemente religiosa (dos mitos e dos ritos), aqueles que possuem fé se comunicam e constituem comunhão. E, dentro do universo da comunhão, a linguagem é responsável, isto é, ela permite que a fé receba um "conteúdo concreto" (TILLICH, 1985, p. 20). Esse conteúdo desdobra-se em confissão da fé, que por sua vez, no curso da história, amplia-se com conteúdos 
dogmáticos desenvolvidos por meio do uso da razão (TILLICH, 1985, p.25). Então, pode-se dizer que, para Tillich, a fé não está separada da existência, ela é simultaneamente subjetiva e empírica, porque impele quem a tem para a vida. Nas palavras de Tillich,

a fé como estar possuído por aquilo que toca incondicionalmente reclama a pessoa inteira e não se deixa restringir à subjetividade do simples sentimento. Tal fé reivindica verdade para si e exige entrega àquilo que toca incondicionalmente. Ela não pode se contentar em ser isolada num canto como sentimento sem compromisso. Quando a pessoa inteira está possuída, todas as suas forças estão tomadas. Se é negada essa reivindicação da religião, nega-se a própria religião. (TILLICH, 1985, p. 30).

Nos termos de Tillich, a fé é algo mais do que sentimento. A fé é algo que impele e compromete o crente a viver sua existência, segundo certos conteúdos que crê serem verdades. Por isso, adiante ele afirma: "A fé tem uma orientação bem determinada e um conteúdo concreto. Por isso ela reclama verdade e entrega" (TILLICH, 1985, p. 30). Por entrega deve-se entender a devoção, mas também o compromisso com a vivência norteada por esse conteúdo. Ora, viver o conteúdo da fé requer do crente que em seu dia a dia siga aquelas verdades nas quais afirma crer. Isto, por certo, significa uma vida social organizada a partir da fé. Temos aí o segundo momento de que falava Higuet, quando a religião dá sentido também ao poder, a autoridade, aos modos de organização, de ações políticas e as normas, sejam elas morais, sociais e ou culturais.

Entretanto, deve-se entender que a divisão mencionada acima entre uma dimensão subjetiva e outra empírica é uma separação estritamente conceitual, cuja finalidade é pedagógica. Para Tillich essa separação não existe na empiria, assim como também não para Joachim Wach. Para este último, a experiência da religião ou do sagrado "envolve atitudes definidas e diferentes formas de expressão" (WACH, 1990, p.31). Faz sentido, então, pensar que existe uma relação intrínseca entre a experiência que antecede a expressão teórica-doutrinária e a expressão cultural da religião (parte prática). Noutras palavras, há uma relação entre mitorito, doutrina-culto e teologia-adoração que não pressupõe a sobreposição de uma 
sobre a outra. "Nenhum ato de adoração pode existir sem alguma concepção do divino, nem uma religião pode funcionar sem pelo menos uma quantidade mítica de expressão cultual" (WACH, 1990, p.32). O ato religioso, portanto, pode ser compreendido como mental-psíquico; todavia, ao manifestar-se fisicamente revelase como psicofísico. Seus grandes campos de expressão, segundo Wach, compreendem o doutrinal, o prático e o sociológico.

Com base em Tillich e Wach, portanto, podemos afirmar a noção pedagógica de que os estudos sobre o fenômeno religioso no âmbito das Ciências da Religião Aplicada abordam-no considerando sua dupla dimensão: uma que podemos chamar dimensão subjetiva (da ordem ontológica) e outra que identificamos como empírica (da ordem da vida social, isto é prática). Para ambos autores, uma dimensão não existe sem a outra, sendo que a primeira deriva de uma experiência que a antecede, que é mítica e que, portanto, define-se como da ordem da fé. A outra, manifesta-se no reino da linguagem (das narrativas e dos ritos) que lhe confere conteúdo concreto organizando a vida social. Noutras palavras, a fé, que é uma experiência subjetiva, tem conteúdo teórico que organiza a expressão cultural da religião por meio das suas doutrinas. Essa é a parte prática da religião.

Esse esquema de estudo da religião matizado nas Ciências da Religião apresenta-se como modelo possível para a abordagem desse fenômeno no ambiente escolar, a partir das propostas da BNCC (2017) e das DCNs (2018). A partir desse esquema é possível abordar também no ER aqueles sistemas de crenças e filosofias de vida não propriamente religiosas, mas que se estruturam em termos similares à religião com narrativas fundantes, símbolos e rituais revestidos de significados que lembram a religião, porque constituem visões de mundo, também tradicionais, porém, seculares.

Após pouco mais de 30 anos de espera, isto é, uma espera que remonta à publicação dos Parâmetros Curriculares Nacionais em 1997, um documento oficial concede espaço para o Ensino Religioso. Em 2017 foi publicado no Diário Oficial da União, a portaria que institui e orienta a implementação da Base Nacional Comum 
Curricular com encaminhamentos pedagógicos para a construção dos programas curriculares da Educação Básica das escolas brasileiras. ${ }^{20}$

Seguindo as prescrições da Constituição Federal (com fundamento no artigo 205 ao 214) e da LDB (Lei $n^{0}$ 9.394/1996), em atenção aos artigos 32 e 33 que definem metas e diretrizes para o Plano Nacional de Educação (PNE), a nova Base Nacional Comum Curricular (BNCC) pela primeira vez propôs parâmetros para orientação do ER nas escolas, do $1^{\circ}$ ano $9^{\circ}$ ano (dos anos iniciais aos anos finais), do Ensino Fundamental (BRASIL, 2017, p. 435-460). Essa conquista não ocorreu sem conflitos. Os laicistas, avessos ao ensino sobre religião nas escolas, mantiveram seus posicionamentos sobre a impossibilidade legal do Estado oferecer e subsidiar uma disciplina dessa natureza, como se fosse impossível tematizar religião no ambiente escolar, sem finalidade proselitista ou confessional (CUNHA, 2016). Ignorantes quanto à área de referência do ER, quanto à história da disciplina de estudos comparados da religião e quanto aos debates sobre CRE Aplicada, os avessos ao Ensino Religioso demonstram ignorar, ainda, as discussões que reconhecem o ensino do fato religioso como conhecimento indispensável para a formação política cidadã, realizadas desde 2002 na própria França, berço do chamado laicismo (DEBRAY, 2002).

O texto da BNCC sugere orientações para uma abordagem do fenômeno religioso que seja baseada em pressupostos científicos, artísticos e pedagógicos. Não se trata de um texto do gênero decreto, cujo conteúdo seria uma série de instituições a serem cumpridas. Contudo, a partir da noção de competência adotada nesse documento, a abordagem do fenômeno religioso, que pretende-se do $1^{0}$ ao $9^{\circ}$ ano, visa indicar para a comunidade discente o que ela precisa "saber" em termos de "conhecimentos, habilidades, atitudes e valores" relacionados às tradições religiosas e filosofias de vida, a fim de que saibam mobilizar tais saberes para "resolver demandas complexas da vida cotidiana, do pleno exercício da cidadania e do mundo do trabalho" (BRASIL, 2017, p.13).

\footnotetext{
${ }^{20}$ Cf. MINISTÉRIO DA EDUCAÇÃO E CULTURA. Portaria n 1.570, publicada no D.O.U. de 21/12/2017, Seção 1, Pág. 146.
} 
Daí que a BNCC pretende, portanto, incentivar a produção de programas de ensino dos diferentes componentes curriculares que subsidiem alunos e alunas a desenvolverem a capacidade de ler e interpretar o mundo ao seu redor. Por isso, para cada componente curricular são definidas habilidades, objetos do conhecimento e unidades temáticas divididas em três eixos: 1) Identidades e alteridades; 2) Manifestações religiosas; 3) Crenças religiosas e filosofias de vida (BRASIL, 2017, p. 436-437).

Tanto os objetos de conhecimento (conteúdos) como as habilidades (competências) para o Ensino Religioso, podem ser reconhecidos como centrais para uma formação política cidadã. Isso porque é notório o incentivo à promoção do conhecimento e da valorização da diversidade religiosa brasileira, como meios para se construir e consolidar ao longo de uma trajetória de nove anos, valores como o respeito e o reconhecimento das alteridades religiosas. Note-se que o ER, nesses termos, não dispensa a noção de valores, mas reconhece-a como resultado desejado de um processo de ensino-aprendizagem sobre o fenômeno religioso (conhecimento religioso). E, aqui vale recuperar o quadro epistemológico que norteia essa construção.

Existem "saberes" oriundos, derivados e relativos ao fenômeno religioso, ou seja, "conhecimentos, habilidades, atitudes e valores" (BNCC, 2017, p. 13) que, ao serem conhecidos pelos(as) estudantes, podem lhes proporcionar a habilidade de "resolver demandas complexas da vida cotidiana, do pleno exercício da cidadania e do mundo do trabalho" (BNCC, 2017, p. 13). Deste modo, saber como a religião se expressa por meio da fé de diferentes tradições religiosas, se materializa numa linguagem real que comunica e que organiza a vida prática dos crentes e torna-se recurso indispensável para que cada estudante elabore suas opiniões e mobilize formas de se relacionar com os diferentes tipos de pessoas crentes e não crentes que existem no convívio social cotidiano. Razão pela qual as orientações para o ER se somam às competências gerais da BNCC, que indicam como prioridade: "Debater, problematizar e posicionar-se frente aos discursos e práticas de intolerância, discriminação e violência de cunho religioso, de modo a assegurar os direitos 
humanos no constante exercício da cidadania e da cultura de paz" (BRASIL, 2017, p. 437). Para a concretização de tal objetivo, o processo deve iniciar pela tematização da religião, da sua parte subjetiva e da sua parte prática, de forma especializada (teórica e epistemologicamente), com o uso de modelos pluralistas de ensinoaprendizagem e com metodologias científicas e criativas de ensino.

Com vistas ao cumprimento desse objetivo, deu-se enfim a redação, discussão, reelaboração e publicação das Diretrizes Curriculares Nacionais para as Licenciaturas em Ciências da Religião, cuja finalidade é garantir a formação adequada de profissionais, tanto para definir a autocompreensão (função), discutir a natureza sociocultural (das habilidades que produz) e pedagógica (da elaboração de objetos do conhecimento) desse componente curricular, quanto para garantir a excelência da formação de educadores e educadoras para o magistério do Ensino Religioso.

\subsection{DCNs para as Licenciaturas em CRE}

Como demonstrado acima, a construção e a homologação da BNCC levantaram a questão quanto à formação docente necessária para se conduzir o componente curricular ER. Como resposta a essa pergunta, em dezembro de 2018 foram homologadas as Diretrizes Curriculares Nacionais para as Licenciaturas em Ciências da Religião (DCNs de CRE), pelo Ministério da Educação/Conselho Nacional de Educação/Secretaria Executiva (MEC/CNE/SE), com a Resolução no 5 , de 28 de Dezembro de 2018. ${ }^{21}$ Esse documento de valor histórico é central para a consolidação de um Ensino Religioso reflexivo, escolar e de caráter laico. Mas é também marco que legitima a associação entre Ciências da Religião e Ensino Religioso, pois afirma esse componente curricular como área de aplicação das CRE e essa ciência como referência para a formação de profissionais da educação que

\footnotetext{
${ }^{21}$ Disponível em: http://www.in.gov.br/materia/-/asset_publisher/Kujrw0TZC2Mb/content/id/57493489/do1-2018-12-31-resolucao-n-5de-28-de-dezembro-de-2018-57493286. Acesso em: 20 nov. 2019.
} 
pretendam o magistério do ensino sobre o fenômeno religioso (conhecimento religioso) nas escolas. ${ }^{22}$

Vale destacar que essa não é uma perspectiva redutiva, se considerarmos o conhecimento religioso como um fenômeno que intersecciona com as várias dimensões da vida, isto é, a histórica, a social, a econômica, a cultural, a psicocognifiva e a sexual. Neste sentido, é competência do ER o ensino sobre o fenômeno religioso (conhecimento religioso) que extrapola os limites da subjetividade (esfera da vida privada) em direção à intersubjetividade e à sociabilidade. E é essa perspectiva que marca a distinção da abordagem do fenômeno religioso no ER em relação ao modo como esse tema é abordado nas Ciências Sociais, História, Filosofia e outras disciplinas. Aqui o que se busca é compreender como o conhecimento religioso se relaciona e afeta, influencia, interpela e ou determina outras dimensões da vida.

A classificação do ER como área de aplicação das CRE, sem desprezar a trajetória histórica desse componente curricular, serve a disciplina com um conjunto de aportes teóricos e metodológicos fundamentais para o ensino sobre o fenômeno religioso e filosofias de vida, enquanto manifestação de diferentes sistemas de referências de dimensão objetiva (histórico-social) e subjetiva (ontológico). O enquadramento teórico, os caminhos metodológicos e a análise crítica sobre a religião, nos termos das CRE, permitirão ao docente de ER o desenvolvimento dos objetos de conhecimento e das habilidades desenhadas na BNCC. Mas chama à atenção que para além da preocupação com a "sólida"

\footnotetext{
${ }^{22}$ Segundo as DCNs, em seu Artigo 3, o curso de licenciatura em Ciências da Religião deverá propiciar:

I - Sólida formação teórico, metodológica e pedagógica no campo das Ciências da Religião e da Educação, promovendo a compreensão crítica e interativa do contexto, a estrutura e a diversidade dos fenômenos religiosos e o desenvolvimento de competências e habilidades adequadas ao exercício da docência do Ensino Religioso na Educação Básica;

II - Sólida formação acadêmico-científica, com vistas à investigação e à análise dos fenômenos religiosos em suas diversas manifestações no tempo, no espaço e nas culturas;

III - O desenvolvimento da ética profissional nas relações com a diversidade cultural e religiosa;

IV - O aprendizado do diálogo inter-religioso e intercultural, visando o reconhecimento das identidades, religiosas ou não, na perspectiva dos direitos humanos e da cultura da paz.

As DCN também oferecem orientações objetivas quanto ao perfil docente adequado para ministrar o componente curricular Ensino Religioso, afirmando, em seu Artigo 4, que tal profissional deve:

I - Atuar com ética e compromisso com vistas à construção de uma sociedade justa, equânime e igualitária; [...]

V - Demonstrar consciência da diversidade, respeitando as diferenças de natureza ambiental-ecológica, étnico-racial, das deficiências e dos diversos modos de ser e viver; [...]
} 
formação teórica, as DCNs tenham sido formuladas tendo em vista 1) a especificidade dos contextos escolares e suas demandas e 2) a criação de condições para a construção de um conhecimento sobre religião que seja esclarecedor do ponto de vista intelectual, mas também compreensivo. Assim, esse ER pressupõe que a compreensão das diferentes tradições religiosas e filosofias de vida pode suscitar entendimentos mútuos, respeito pelas diferenças e a capacidade para o convívio harmonioso entre as alteridades.

Nesse sentido, os encaminhamentos dados nas DCNs de CRE orientarão docentes de todo o país a comporem seus programas de ensino sobre as tradições religiosas e sistemas de crenças não-religiosas, atentos as suas realidades regionais e às especificidades locais do campo religioso em que estão inseridas as suas escolas. A formação adequada e a qualificada para o ER, portanto, emergem como estratégia fundamental para a consolidação desse componente curricular como há 30 anos afirma o artigo 33 da LDB, Lei no 9.475, de 22 de julho de 1997:

O ensino religioso, de matrícula facultativa, é parte integrante da formação básica do cidadão e constitui disciplina dos horários normais das escolas públicas de ensino fundamental, assegurado o respeito à diversidade cultural religiosa do Brasil, vedadas quaisquer formas de proselitismo.

Importante notar que o texto da lei assegura aos educandos e educandas o direito à matrícula em Ensino Religioso (art. 211 da Constituição Federal de 1988). Direito que somente pode ser exercido caso o componente curricular seja oferecido pela unidade escolar. Quando, portanto, a escola não oferece ao aluno ou a aluna a possibilidade de matrícula, tal unidade escolar está alijando o cidadão e ou a cidadã do direito à formação básica. Não são raras as unidades da Federação (Estados e municípios) que alegam não terem condições de oferecerem ER em razão da ausência de profissionais especializados para a construção de seus currículos, em razão da falta de profissionais qualificados para o magistério e ou em razão de não terem a estrutura adequada para receberem possíveis discentes que não queiram cursar o ER. 
Embora as algumas justificativas sejam legítimas, tanto a BNCC quanto as DCNs para CRE representam marcos legais cuja finalidade é responder a tais lacunas. Cabe às Secretarias de Educação, aos(as) gestores, profissionais educadores(as) e pesquisadore(as), junto à sociedade civil se organizarem em prol da implementação desse componente curricular, agora, respaldados pelos textos legais mais recentes. Textos que não apenas exprimem intenções para a educação, como apontam caminhos pedagógicos e epistemológicos por meio da explicitação de princípios gerais, a partir dos quais se pode compreender mais apuradamente a especificidade dos discursos e das práticas religiosas.

As DCNs, por exemplo, pressupõem como princípio a possibilidade de investigação da religião como dado sociocultural e intersubjetivo, possível desde a crítica iluminista e a Modernidade. Esses eventos históricos ao conduzirem o pensamento, no Ocidente, à fragmentação das ciências em áreas específicas de pesquisa permitiram o surgimento e o interesse das Ciências Humanas pela religião como objeto. Contribuiu para esse processo o conjunto de informações que a Europa reuniu por ocasião de seus esforços colonizadores dos continentes africano, americano e asiático. Pode-se então compreender que o processo colonizador e as missões religiosas ao se expandirem pelos mares rumo à ocupação de diferentes territórios (muitos deles já ocupados, geopoliticamente organizados, com sociedades e culturas estabelecidas) acabaram por descobrir uma diversidade de outros povos, culturas e religiões. Essa descoberta é que possibilitou condições para o reconhecimento e posterior formulação da noção de pluralismo cultural importante para a modernidade.

Decorre que ao entender o pluralismo cultural como realidade histórica e social mais ampla, o estudo comparativo de tais grupos sociais, suas tradições e costumes levou à percepção da religião como topos. Novamente, a religião como algo que extrapola o campo da crença e a emancipa dos círculos clericais, introduzindo-a no interior dos centros universitários e de produção de saber. Nesses espaços importa compreender a religião como algo que ocupa lugar na vida humana, como uma das suas dimensões. Este pode ser considerado outro princípio 
que orienta o texto das DCNs: compreender a religião como dimensão da vida humana (subjetiva e objetiva) é desígnio de uma educação destinada à formação cidadã plena.

Este princípio liga-se a outro que orienta a autocompreensão (função) do Ensino Religioso nos currículos escolares, especialmente dos sistemas públicos de educação: a natureza do Ensino Religioso não é evangelizar, catequizar e ou fomentar a espiritualidade individual ou coletiva de educadores(as) ou de educandos(as). Essa tarefa cabe aos núcleos de familiares e responsáveis, bem como aos grupos religiosos (igrejas, denominações, instituições religiosas). A natureza do Ensino Religioso é ensinar sobre as religiões, os sentidos e filosofias de vida (narrativas e discursos) e as práticas (rituais e costumes), suas funções e os lugares, que ocupam e cumprem na história da humanidade. O Ensino Religioso aborda o conhecimento, o pensamento e a produção religiosa (histórica, social e cultural), na perspectiva de contribuir para uma formação cidadã plena de instrumentos para reconhecer e respeitar o pluralismo de ideias e de crenças religiosas e seculares.

Com base nessa tríplice fundamentação pode-se afirmar que os estudos de religião que se desenvolvem no interior do ER orientado pelas CRE visam atinar para a religião ou o religioso considerando-lhe: (a) a região da atribuição de sentidos e (b) a dimensão do desdobramento desses significados - ou a capacidade de interpelação desses sentidos -, nas outras dimensões da vida humana: a social, a política, a econômica, a cultural e a sexual.

A fim de conceder essa fundamentação aos profissionais do ER, a formação dos(as) licenciados(as) em Ciências da Religião divide-se entre uma parte teóricosistemática e outra de estudos empíricos e práticos. O que distingue a licenciatura em CRE de outras áreas que também, em alguma medida, dedicam-se ao estudo da religião é que ela prepara para o ensino sobre o fenômeno religioso (conhecimento religioso) tomando-o como objeto por excelência. Importa para as licenciaturas em CRE preparar e capacitar seus profissionais a observarem, compararem e analisarem os diferentes modos de crer, com a finalidade de compreendê-los desde 
sua história, passando por sua morfologia e chegando até suas teologias e práticas rituais. É, pois, uma formação de ênfase compreensiva que pretende tanto conceder conhecimento sobre religião para seus profissionais quanto fomentar neles a capacidade de ler e interpretar o universo simbólico das tradições religiosas nas suas relações com mundo.

A perspectiva compreensiva na formação dos(as) profissionais do Ensino Religioso é que lhes facultará os instrumentos epistemológicos e pedagógicos para a aplicação do conjunto de saberes das CRE ao contexto da prática de ensino escolar. Para essa prática não há bula. Neste sentido, o gênero das DCNs de CRE é semelhante ao gênero da BNCC. O texto caracteriza-se por apresentar princípios e, portanto, por não ser um texto normativo. Subentende-se que a licenciatura em CRE prepara profissionais para aplicarem os saberes derivados dos estudos de religião ao contexto específico do Ensino Fundamental e às demandas de cada etapa do desenvolvimento psíquico-cognitivo dos(as) estudantes. Por isso, tanto o caráter dessa formação quanto o próprio componente curricular ER não correspondem a simples transposição dos conteúdos de um curso de CRE para a Educação Básica.

Isso significa que, segundo as DCNs de 2018, as Licenciaturas em CRE deverão preparar docentes para o ensino sobre o fenômeno religioso (conhecimento religioso), isto é, sobre as diferentes tradições religiosas e filosofias de vida, suas narrativas, suas práticas, seus ensinos e seus códigos de usos e costumes, em ambientes escolares. Nestes termos, as CRE constituem a área de conhecimento que serve à formação profissional de educadore(as) para o ER e para o magistério desse componente curricular como campo de referência, que lhe proporcionará os aportes teóricos e metodológicos adequados para o ensino sobre o fenômeno religioso (conhecimento religioso) ou sobre o fenômeno religioso na escola. ${ }^{23}$

\footnotetext{
23 “[...] objetivos, conteúdos, estratégias e procedimentos necessários para a abordagem das religiões, ressaltando-lhes a relevância pragmática e ontológica e contribuindo para a formação de cidadãos críticos quanto à qualidade e aos limites das religiões no âmbito social. A formação oferecida pela Ciência da Religião tem condições de superar o proselitismo historicamente atribuído ao Ensino Religioso, pela superação do comprometimento com instituições religiosas, pelo compromisso de rigor teórico-metodológico e pelo avanço dos reducionismos forjados no âmbito de outras disciplinas cujo objeto central é outro que não a religião." (RODRIGUES, 2013, p. 240).
} 


\section{Da aplicação da Ciência da Religião à Educação}

No âmbito das discussões realizadas por educadores e educadores em centros de pesquisa e em universidades existem temas candentes, que impactam também os estudos de religião. Abordar o crente (de qualquer religião), assim como aqueles e aquele(as) que não professam fé religiosa, como sujeito do conhecimento, bem como empregar práticas inovadoras para o ensino em contexto escolar são dois desses temas. Para ambos, a postura que se requer de educadores é que sejam reflexivos(as), críticos(as), criativos(as) e "desconstrucionistas" em suas posturas. O que isso significaria para pessoas interessadas na relação religião e educação?

Os termos que usamos dizem muito a respeito da orientação de uma discussão. Ao empregarmos no contexto do ER brasileiro expressões como "sujeitos do conhecimento" e "práticas inovadoras" supõe-se o ER como componente curricular constituído por reflexões e práticas de ensino elaboradas e executadas por pessoas que são ativas na história, comprometidas com reflexões autônomas e críticas, além de interessadas num tipo de produção de conhecimento sobre religião que esteja substanciada também por elementos da vida cotidiana. O que a BNCC chama de campos de experiência. Embora oficialmente a noção de campos de experiência seja empregada na BNCC apenas com respeito à Educação Infantil, parece-nos produtiva a sua compreensão pedagógica para a finalidade do ensino sobre conhecimento religioso no Ensino Fundamental, especialmente, nos anos iniciais que correspondem do $1^{0}$ ao $4^{0}$ anos. Segundo a BNCC:

Os campos de experiências constituem um arranjo curricular que acolhe as situações e as experiências concretas da vida cotidiana das crianças e seus saberes, entrelaçando-os aos conhecimentos que fazem parte do patrimônio cultural. (BNCC, 2017, p. 38).

Aplicar as CRE ao ER requer que seja levada a sério a tarefa de reunir chaves para, ao olhar a religião na nossa realidade social, termos instrumentos que nos ajudem a compreender: (a) em que lugar está a religião (nas redes sociais, nos programas de TV, no planalto central, na música, na geografia da cidade, na escola)? 
(b) como nesses lugares a religião interfere por meio de seus discursos, das suas narrativas sagradas, dos seus costumes, das suas teologias e dos seus dogmas? (c) como a relação da religião com esses lugares resulta na transformação da própria religião e de seus discursos gerando novas práticas e orientações para as pessoas religiosas? Isto porque tanto o ER quanto a CRE entendem o fenômeno religioso como um dado da realidade social, que afeta de distintas formas a todos e todas que convivem em sociedade.

Ao procurar responder essas questões, o educador e a educadora de ER assumem a postura de sujeitos do conhecimento, porque ao falarem da religião a partir de temas geradores participam do processo de produção do conhecimento sobre a religião. Logo, são também sujeitos do conhecimento a construir discursos sobre a religião, o que é por natureza diferente de apenas reproduzir em sala de aula os discursos religiosos sem contestá-los.

Essa postura, então, conduz à prática inovadora que vai além da exposição oral de conteúdos. Por práticas que inovam subentende-se dinâmicas de ensino que promovam oportunidades para que educandos e educandas saibam sobre religião, a partir de outros tipos de experiências que os envolvam também com a religião. Trazer para a sala de aula as narrativas, os símbolos, as roupas, os instrumentos religiosos é um meio produtivo de se tematizar religião a partir do campo de experiência de cada um/uma. Mas também levá-los aos espaços religiosos. Mapear bairros e cidades e verificar onde as religiões marcam presença com seus nomes, divindades e costumes significa valorizar a linguagem e a materialidade da religião como conhecimentos disponíveis, com os quais lida-se no cotidiano.

Ao trazê-las para o interior da aula, conferindo-lhes espaço de expressão por meio das vozes dos(as) próprios(as) educandos(as) e a partir de seus campos de experiência, as religiões tornam-se mais familiares e humanas. Especialmente, quando são mapeadas e acolhidas as demandas dos(as) estudantes. Ao ouvir de cada um/uma os seus relatos sobre o que conhecem da religião por meio do que viram, ouviram e tocaram, por meio da vida em comunidade, por meio da geografia do bairro, da escuta do rádio, do acesso as mídias sociais e outros meios, o 
conhecimento sobre o religioso, bem como o conhecimento religioso tornam-se a matéria principal do ER.

Pode-se dizer então que o ER contemporâneo tem uma vocação que é desconstrucionista, porque ao se colocar as religiões num patamar de igualdade, seja na hora de apontar o que ela tem de bom, seja na hora de problematizar o que pode ser considerado nocivo, desconstrói-se a noção de que existem religiões melhores do que outras.

Neste sentido, ampliar o conhecimento sobre as religiões comparativamente permite a desconstrução de preconceitos, assim como a possibilidade de crítica aos sistemas de classificações, por pares de oposição, naturalizados pela Academia, tais como: primitivo-evoluído, científico-místico, discursivo-sensorial, intelectualemocional. Por isso, a importância de uma ação pedagógica que estabeleça os conteúdos do ER a partir das realidades sociais, culturais e históricas mais próximas, nacionais e regionais, adequando as orientações propostas da BNCC à realidade de cada estado e município, com currículos de referência. Assim fazendo o movimento do local para o global.

Tal ação tem potencial incrível, por exemplo, se tomar por objeto as religiões ameríndias e as religiões afro-brasileiras. Isto porque seu alcance, impacto e efeito poderia contribuir efetivamente para o diálogo inter-religioso, o combate à intolerância religiosa e a promoção do respeito pelas alteridades, simplesmente se concebermos que a ampliação do conhecimento sobre tais religiões implicaria na erradicação da ignorância sobre elas. Daí a importância do pluralismo como princípio pedagógico e a valorização do local como estratégia para fortalecê-lo. A efetividade do ER contemporâneo reside na abordagem das religiões dos terreiros, as religiões dos templos pentecostais, as religiões de êxtase, as religiões que admitem múltiplas pertenças. O ER ministrado por um educador ou educadorasujeitos do conhecimento deve assegurar o tratamento da religião que nossos 
discentes conhecem mais proximamente 24 . Embora neste artigo não tenhamos espaço para destacar ações que implementam essa perspectiva, cabe-nos salientar que esse procedimento tem início com a construção de um ambiente acolhedor e de respeito, propício à descoberta e ao diálogo entre discentes, docentes, profissionais da educação e comunidade escolar. Algo possível com a prática recorrente de um mapeamento do campo religioso escolar.

Então, retomamos as considerações anteriores segundo as quais indicamos que o ER contemporâneo, que se pretende inovador, busca valer-se de chaves e instrumentos teóricos das Ciências da Religião (CRE), para reinventar o próprio saber sobre o religioso e o saber daqueles(as) que o promovem, isto é, de docentes e discentes.

Neste sentido, pode-se considerar de caráter inovador a perspectiva fenomenológica como chave para uma prática de ensino sobre o fenômeno religioso (conhecimento religioso) nas escolas. Essa perspectiva diz respeito a uma forma, portanto, um caminho, de se abordar a religião. Vale assinalar que o fundamento fenomenológico no âmbito do ER não é uma metodologia acabada, mas, volto a dizer, uma postura que o(a) professor(a) assume diante a religião. Uma atitude docente curiosa e investigativa que visa apreendê-la sob o ponto de vista: (1) Pragmático (do valor histórico, social e cultural) e (2) Ontológico (do valor simbólico que confere aos sujeitos religiosos dispositivos para a significação da vida). Isto porque, assim como Wach apontou ser um entendimento relevante das Ciências da Religião, também para o Ensino Religioso é central ressaltar que o objeto desse componente curricular possui dupla dimensão, a que identificamos como empírica (da ordem da vida social, isto é, prática) e a outra subjetiva (da ordem ontológica).

Dessa forma, associa-se à perspectiva fenomenológica de abordagem da religião, o enquadramento metodológico que vê na parte empírica da religião o

\footnotetext{
${ }^{24}$ Orientação já prevista na lei, no artigo 210 da Constituição Federal de 1988. Esse artigo estabelece que os conteúdos mínimos para o ensino fundamental devem assegurar formação básica comum e respeito aos valores culturais e artísticos, nacionais e regionais.
} 
material necessário para melhor compreendê-la. As religiões podem ser melhor conhecidas e compreendidas quando observadas em campo. A partir dessa prática que se obtém dados, informações, imagens e pistas que permitem a montagem do "quebra-cabeça", ou, em outros termos, a formulação de conceitos autônomos, formulados pelos(as) próprios discentes do que seja religião.

Para montar esse quebra-cabeça, o procedimento é investigativo, como é o processo de construção de conhecimento, como é a postura da criança diante o mundo: primeiro se observa, depois se descreve e, então, se faz a comparação. Cientificamente, (1) observação e descrição, (2) comparação com outras religiões colocadas num quadro e, por fim, (3) identificação de estruturas que porventura se repitam entre tais religiões, isto é, síntese.

A elaboração de quadros comparativos é substancialmente um recurso metodológico fenomenológico, porque desse quadro emergem desde similaridades entre as religiões comparadas, até continuidades e rupturas. E é desse conjunto de evidências de estruturas recorrentes e estruturas que se rompem, dando lugar a outras novas, que surgem conceitos, noções e categorias para a ampliação do conhecimento sobre as religiões. E, desse procedimento, que não é apenas acadêmico, mas prática da vida, se constitui material para que se chegue à compreensão da religião, enquanto objeto de estudo e dimensão da vida humana.

\section{Considerações finais}

Com este artigo, cujo tema principal é o Ensino Religioso como campo de aplicação das CRE, procurou-se demonstrar em que medida essa área de referência serve ao ER, entendido como componente curricular do Ensino Fundamental brasileiro, especialmente nos sistemas públicos de educação.

Ao longo do artigo apresentamos argumentos que supõem que esse caminho leva-nos à produção de instrumentos reflexivos, criativos e críticos, os quais permitem aos sujeitos desse conhecimento (docentes e discentes) acesso a um 
conhecimento significativo sobre o fenômeno religioso presente no cotidiano das relações sociais, por meio da pluralidade de ideias e crenças religiosas e seculares.

Tal conhecimento significativo, ao nosso ver, é capaz de subsidiar noções objetivadas tanto pela BNCC quanto pelas DCNs, tais como reconhecimento das alteridades e o respeito pelas diferenças. É, portanto, um conhecimento significativo não apenas para os documentos e ou para a Academia, mas um conhecimento potente para consolidar dinâmicas sociais mais equânimes, harmoniosas e condizentes com uma sociedade que reconhece e respeita as alteridades.

\section{REFERÊNCIAS}

BRASIL. Constituição da República Federativa do Brasil (1988). In Diário Oficial da União $\mathrm{n}^{\circ}$. 191-A, de 5 de outubro de 1988. Disponível em:

http://www.planalto.gov.br/ccivil_03/constituicao/constituicaocompilado.htm. Acesso em: 13 de jan. 2020.

BRASIL. Lei de Diretrizes e Bases da Educação Nacional. Lei no $.9 \cdot 475 / 97$, de 22 de julho de 1997. Nova redação atribuída ao Artigo 33 da Lei no $.9 .394 / 96$, que estabelece Diretrizes de Base da Educação Nacional. In Diário Oficial União, Brasília, Congresso Nacional, 1997. Disponível em: http://www.planalto.gov.br/ccivil_03/Leis/l9475. htm. Acesso em: 13 de jan. 2020.

BRASIL. Lei de Diretrizes e Bases da Educação Nacional. Lei nº . 9.394/96. In Diário Oficial União (1996)., Poder Legislativo, Brasília, DF, 23 dez. 1996, p. 27833. Disponível em: https://www.planalto.gov.br/ccivil_03/Leis/L9394.htm. Acesso em: 13 de jan. 2020.

BRASIL. Ministério da Educação. Conselho Nacional de Educação; Câmara de Educação Básica. Resolução no 7, de 14 de dezembro de 2o10. Fixa Diretrizes Curriculares Nacionais para o Ensino Fundamental de 9 (nove) anos. In Diário Oficial da União, Brasília, 15 de dezembro de 2010, Seção 1, p. 34. Disponível em:

http://portal.mec.gov.br/dmdocuments/rceboo7_10.pdf. Acesso em: 13 de jan. 2020.

BRASIL. Plano Nacional de Educação - PNE (2001). Disponível em: http://portal.mec. gov.br/arquivos/pdf/pne.pdf. Acesso em: 13 de jan. 2020.

BRASIL. Resolução no. 4/2010. Define Diretrizes Curriculares Nacionais Gerais para a Educação Básica. Promulgada em 13 de julho de 2010. Disponível em: http://portal.mec.gov.br/dmdocuments/rcebo04_10.pdf. Acesso em: 13 de jan. 2020.

DEBRAY, Régis. L'Enseignement du fait religieux dans l'école laïque. Préface de Jack Lang. Paris: Éditions Odile Jacob/Services Culture Éditions, 2002b. 
DEBRAY, Régis. Le "fait religieux": définitions et problèmes. In: Programme national de pilotage. L'enseignement du fait religieux. Actes du séminaire national interdiciplinaire, organisé à Paris les 5, 6 et 7 novembre 2002.

GEARON, Liam. The Paradigms of Contemporary Religious Education. Journal for the Study of Religion, v. 27, n. 1, p. 52-81, 2014.

JUNQUEIRA, Sérgio Rogério Azevedo. Ciência da Religião Aplicada ao Ensino Religioso. In: PASSOS, João Décio; USARSKI, Frank (org.). Compêndio de Ciência da Religião. São Paulo: Paulus: Paulinas, 2013. p. 603-614.

JUNQUEIRA, Sérgio Rogério Azevedo. Uma ciência como referência: uma conquista para o Ensino Religioso. REVER: revista de estudos da religião, São Paulo, v. 15, n. 2, p. 10-25, 2015 .

MARTIN, Luther; WIEBE, Donald. Religious studies as a scientific discipline: The persistence of a delusion. Journal of the American Academy of Religion, v. 80, n. 3, p. 587-597, 2012.

MINISTÉRIO DA EDUCAÇÃO E CULTURA. BNCC - Base Nacional Comum Curricular, 2017. Disponível em:

http://basenacionalcomum.mec.gov.br/images/BNCC_EI_EF_110518_versaofinal_site.pd f. Acesso em: 13 jan. 2020.

MINISTÉRIO DA EDUCAÇÃO E CULTURA. Documento de área. Área 44: Ciência da Religião e Teologia, 2019b. Disponível em:

https://www.capes.gov.br/images/Documento_de_\%C3\%A1rea_2019/ciencia_religiao_te ologia.pdf. Acesso em: 21 de novembro de 2019.

MINISTÉRIO DA EDUCAÇÃO. Diário Oficial da União, Brasília, 20 de dezembro de 2019, p. 246. PORTARIA No 2.167, de 19 de dezembro de 2019a. Disponível em:

http://pesquisa.in.gov.br/imprensa/jsp/visualiza/index.jsp?data=20/12/2019\&jornal=515 \&pagina $=142 \&$ totalArquivos $=289$. Acesso em: $21 \mathrm{dez} .2019$.

PASSOS, João Décio. Ensino religioso: construção de uma proposta. são Paulo: Paulinas, 2007.

PASSOS, João Décio. Ensino Religioso: mediações epistemológicas e finalidades pedagógicas. In SENA, Luzia (org.). Ensino religioso e formação docente: Ciências da Religião e Ensino Religioso em diálogo. São Paulo: Paulinas, 2006. p. 21-45.

PASSOS, João Décio. Epistemologia do Ensino Religioso: do Ensino à Ciência, da Ciência ao Ensino. Rever, São Paulo, ano 15, n. 2, p. 2-44, jul./dez. 2015.

PASSOS, João Décio; MENEGHETTI, Rosa Gitana Krob. O Ensino Religioso como área de conhecimento: contribuições à discussão no Conselho Nacional de Educação - 2001. In: SENA, Luzia (org.). Ensino religioso e formação docente: Ciências da Religião e Ensino Religioso em diálogo. São Paulo: Paulinas, 2006, p. 111-139. 
PASSOS, João Décio; USARSKI, Frank (org.). Compêndio de Ciência da Religião. São Paulo: Paulinas, 2013. p.573-576.

PIEPER, Frederico. Aspectos históricos e epistemológicos da Ciência da Religião no Brasil: Um estudo de caso. Numen: revista de estudos e pesquisa da religião, Juiz de Fora, v. 21, n. 2, p. 232-291, jul./dez. 2018.

PIEPER, Frederico. Religião: limites e horizontes de um conceito. Estudos de Religião, São Bernardo do Campo, v. 33, n. 1, p. 5-35, jan.-abr. 2019.

RIBEIRO, Flávio Augusto Senra. Documento de área. Área 44: Ciências da Religião e Teologia. Brasília, DF: MEC/CAPES, 2019.

RODRIGUES, Elisa. Ensino Religioso e área de conhecimento. In: JUNQUEIRA, S. R. A.; BRANDENBURG, L. E.; KLEIN, R. (org.). Compêndio do Ensino Religioso. São Leopoldo: Sinodal; Petrópolis: Vozes, 2017. p. 117-130.

RODRIGUES, Elisa. Questões epistemológicas do Ensino Religioso: Uma proposta a partir da Ciência da Religião. Interações - Cultura e Comunidade, Belo Horizonte, v. 8, n. 14, p. 230-241, jul./dez. 2013.

SMART, Ninian. Worldviews. Crosscultural Explorations of Human Beliefs. New York: Charles scribner's Sons, 1983.

SOARES, Afonso M. L. Ciência da Religião, Ensino Religioso e formação docente. REVER: revista de estudos da religião, n. 3, p. 1-18, set. 2009.

SOARES, Afonso M. L. Religião \& educação: da Ciência da Religião ao Ensino Religioso. São Paulo: Paulinas, 2010. (Coleção temas do ensino religioso).

STERN, Fábio L.; COSTA, Matheus O. (org.). Ciência da Religião Aplicada: ensaios pela autonomia e aplicação profissional. Porto Alegre: Fi, 2018.

TILLICH, Paul. Dinâmica da fé. 3. ed. São Leopoldo: Sinodal, 1985.

TWORUSCHKA, Udo. Ciência Prática da Religião: considerações teóricas e metodológicas. In: PASSOS, João Décio; USARSKI, Frank (org.). Compêndio de Ciência da Religião. São Paulo: Paulus: Paulinas, 2013. p. 577-588.

TWORUSCHKA, Udo. Considerações sobre a ciência prática da religião. In: STERN, Fábio L.; COSTA, Matheus O. (org.). Ciência da Religião Aplicada: ensaios pela autonomia e aplicação profissional. Porto Alegre: Fi, 2018. p. 31-61.

WACH, Joachim. Sociologia da religião. São Paulo: Paulinas, 1990.

WIEBE, Donald. The Politics of Wishful Thinking? Disentangling the Role of the ScholarScientist from that of the Public Intellectual in the Modern Academic Study of Religion.

Temenos - Nordic Journal of Comparative Religion, v. 41, n. 1, p. 7-38, 2005.

WIEBE, Donald. Why the Academic Study of Religion? Motive and Method in the Study of Religion. Religious Studies, v. 24, n. 4, p. 403-413, 1988. 